\title{
HUBUNGAN KOMUNIKASI PERAWAT DENGAN TINGKAT KECEMASAN KELUARGA PASIEN DI UNIT PERAWATAN KRITIS
}

\author{
Dwi Retnaningsih'), Elisabeth Etikasari²) \\ 1 Program Studi S1 Keperawatan STIKES Widya Husada Semarang \\ 2 RSUD Salatiga \\ email: dwiretnaningsih81@yahoo.co.id
}

\begin{abstract}
Anxiety will be more clearly observed among patients and families in the Critical Care Unit. Nurses can provide understanding and therapeutic approach to patients and their familia are realized with the implementation of effective communication between nurses with patients and their families throughtherapeutic communication. This study is to know the therapeutic nurse communication relationships with family anxiety levels of patients undergoing treatment at the Salatiga Hospital Critical Care Unit. A descriptive study design was conducted to investigate 24 samples. Spearman Rank test was administered to examine the correlation between nurse therapeutic communication and family's anxiety. Results revealed that mostly nurse performed a good therapeutic, while patient's family suffered from mid $(66.7 \%)$ to severe $4.2 \%$ anxiety. There was no significant relationship between therapeutic communication and famili's anxiety ( $(r=-0,213 ; p: 0.319)$. We suggested nurses to improve the quality of nursing services in particular on the attitudes and skills in communicating that nurses do.
\end{abstract}

Keywords: nurse comunication, anxiety, family, critical care

\begin{abstract}
ABSTRAK
Kecemasan lebih jelas terlihat pada pasien-pasien dan keluarga yang di rawat di unik prawata kritis. Perawat dapat menyediakan diri memahami dan melakukan pendekatan komunikasi terapeutik dan komunikasi efektif. Penelitian ini untuk menguji hubungan antara komunikasi terapeutik oleh perawat dan tingkat kecemasan keluarga pasien yang dirawat di ruang perawata kritis di RSUD Salatiga. Penelitian deskriptif dilaksanakan untuk mengobservasi 24 sample. Uji Spearman Rank dilakukan untuk uji hubungan antara kedua variabel. Hasil penelitian menunjukkan kebanyakan perawat sudah melakukan komuniikasi terapeutik dengan baik $(0.75)$, sedangkan keluarga pasien kebanyangan mengalami kecemasan sedang $(66.7 \%)$ sampai dengan berat (4.2\%). Tidak terdapat korelasi bermakna antara komunkasi terapeutik perawat dan kecemasan keluarga ( $r=-0,213 ; \mathrm{p}: 0.319)$. Disarankan perawat untuk meningkatkan kualitas pelayan khususnya sikap dan kemampuan dalam berkomunikasi dalam melakukan tingkan keperawatan
\end{abstract}

Kata kunci: komunikasi terapeutik, kecemasan, perawatan kritis, keluarga 


\section{PENDAHULUAN}

Dalam praktek keperawatan profesional perawat memegang tanggung jawab yang sangat besar, dimana perawat dituntut untuk melaksanakan perannya selama 24 jam berada di samping pasien dan keluarganya. Pasien bersama keluarganya yang masuk rumah sakit (MRS) akan mengalami perasaan cemas atau yang sering disebut ansietas. Perasaan cemas atau ansietas ini akan lebih jelas ditemukan pada pasien dan keluarga yang MRS dalam Critical Care Unit. Penelitian menunjukkan bahwa keluarga akan mengalami ansietas dan disorganisasi perasaan ketika anggota keluarganya MRS dengan penyakit kritis atau terminal, ini disebabkan mereka tidak mampu untuk membangun dukungan bagi klien dan mereka sering terlihat kesulitan bekerja sama dengan perawat. Perasaan frustasi dan permusuhan dengan staf perawatan pada prinsipnya akan selalu berada bersama pasien dan keluarganya selama 24 jam. Hal ini menimbulkan kebingungan dan meningkatkan stress dan kemarahan dalam diri keluarga terhadap staf perawat (Stuart, 2009).

Sebenarnya hal demikian tidak akan terjadi apabila sejak dari pertama kali pasien MRS, perawat mampu memberikan pengertian dan pendekatan yang terapeutik kepada pasien dan keluarganya yang diwujudkan dengan pelaksanaan komunikasi yang efektif antara perawat dengan pasien dan keluarganya melalui komunikasi terapeutik. Namun demikian dari beberapa hasil penelitian diketahui bahwa komunikasi terapeutik perawat masih kurang baik (Smet, 2004; Saelan, 2008). Bahkan Dr. Makmur Sentosa di RSU Kardinah pada seminar PPNI yang dimuat
Harian Umum Suara Merdeka tanggal 18 Juni 2001, mengatakan bahwa salah satu permasalahan terhadap pelayanan kesehatan adalah komunikasi yang kurang baik antara tenaga kesehatan dan pasien.

Ketrampilan berkomunikasi bukan merupakan kemampuan yang kita bawa sejak lahir dan juga tidak akan muncul secara tiba - tiba saat kita memerlukannya. Ketrampilan tersebut harus dipelajari dan dilatih secara terus menerus melalui kemampuan belajar mandiri, penyegaran dan pelatihan terutama berhubungan dengan upaya untuk mendapatkan pengetahuan, sikap dan ketrampilan yang diperlukan (Sullivan, et all, 1995 dalam Tomey, 2006). Selain itu, faktor-faktor penghambat komunikasi merupakan faktor yang dapat mengganggu atau sama sekali bisa membuat perawat tidak mampu berkomunikasi secara terapeutik. Solusi-solusi ini dapat dijadikan pilihan karena bertujuan membantu tenaga kesehatan profesional (termasuk perawat) memperbaiki penampilan kerja guna memberikan pelayanan keperawatan yang berkualitas.

Pada umumnya pasien yang datang di unit perawatan kritis ini adalah dalam keadaan mendadak dan tidak direncanakan, hal ini yang menyebabkan keluarga dari pasien datang dengan wajah yang sarat dengan bermacammacam stressor yaitu ketakutan akan kematian, ketidakpastian hasil, perubahan pola, kekhawatiran akan biaya perawatan, situasi dan keputusan antara hidup dan mati, ketidakberdayaan untuk tetap atau selalu berada disamping orang yang disayangi sehubungan dengan peraturan kunjungan yang ketat, tidak terbiasa dengan perlengkapan atau 
lingkungan di unit perawatan kritis, personel atau staf di ruang perawatan, dan rutinitas ruangan (Perry \& Potter, 2005).

Dari hasil pengamatan penulis selama di Rumah Sakit Umum Daerah Kota Salatiga, terdapat kecenderungan yang terjadi yaitu nampak pada hubungan interpersonal perawat dengan pasien dan keluarganya ditunjukkan dengan komunikasi antara perawat tidak terapeutik saat berinteraksi dengan pasien dan keluarganya, ada beberapa keluhan pasien dan keluarganya terhadap pelayanan yang diberikan yang seharusnya bisa diatasi dengan komunikasi terapeutik dari perawat. Hasil dari kotak saran di Ruang ICU selama tahun 2010, didapatkan bahwa terdapat tingkat kepuasan terhadap pelayanan di Ruang ICU yaitu tingkat kepuasan kategori baik sejumlah 49,25\%, kategori cukup sebanyak $48,51 \%$ dan 2, $24 \%$ dalam kategori tidak puas. Berdasarkan hasil pengamatan dan fenomena tersebut, maka penulis tertarik untuk meneliti hubungan komunikasi yang dilakukan perawat terhadap penurunan tingkat kecemasan keluarga pasien yang menjalani perawatan di Unit Perawatan Kritis RSUD Kota Salatiga.

\section{METODE PENELITIAN}

Jenis penelitian ini adalah penelitian deskriptif korelasi, yaitu penelitian yang dilakukan untuk menggambarkan variabel-variabel penelitian dan menganalisis hubungan antara variabel bebas (komunikasi perawat) dengan variabel terikat (tingkat kecemasan keluarga pasien). Rancangan penelitian yang digunakan adalah cross sectional (belah lintang), dimana peneliti mengukur data komunikasi perawat dan kecemasan keluarga pasien pada waktu sesaat atau sama. Penelitian dilakukan di Rumah
Sakit Umum Daerah Kota Salatiga di Ruang ICU. Instrumen dalam penelitian ini berupa lembar kuesioner yang terdiri atas 3 (tiga) bagian yaitu Bagian 1 digunakan untuk menggali data biografi sampel penelitian mencakup umur, jenis kelamin, status hubungan dengan pasien, dan tingkat pendidikan; Bagian 2 digunakan untuk menggali tentang kemampuan komunikasi pasien berdasarkan persepsi sampel penelitian; dan Bagian 3 digunakan untuk mengukur tingkat kecemasan sampel penelitian menggunakan kuesioner baku dari Hamilton Anxiety Rating Scale (HARS), sehingga tidak perlu dilakukan uji validitas dan reliabilitas.

\section{HASIL DAN PEMBAHASAN}

\section{Gambaran Umum Lokasi Penelitian}

Penelitian dilakukan di RSUD Kota Salatiga yang beralamat di JI Osamaliki 19, Kota Salatiga. Berdiri sejak 1978 yang merupakan RS tipe $D$, dan sejak tahun 2008 menjadi Badan Lembaga Usaha Daerah Kota Salatiga. Berdiri diatas tanah milik Pemerintah Kota Salatiga seluas \pm $33.600 \mathrm{~m}^{2}$. Jumlah tempat tidur pada tahun 2008 sebanyak 212 buah. RSUD Kota Salatiga terletak di tengah Kota Salatiga, berada di jalan arteri primer Semarang - Solo, berjarak $\pm 47 \mathrm{KM}$ dari Semarang, $\pm 53 \mathrm{KM}$ dari Solo, dan 100 KM dari Yogyakarta.

Di ICU RSUD Kota Salatiga jumlah tempat tidur ada 4 buah dengan monitoring bedside. Dengan kepala instalasi dokter spesialis anestesi, dokter jaga ICU ada 7 orang dan perawat terlatih 13 orang yang terdiri (1 kepala bangsal, 1 wakil kepala dan 11 perawat pelaksana). Standar pelayanan ICU adalah pemberian pelayanan resusitasi jantung paru, pengelolaan jalan nafas, terapi 
Tabel 1 Karakteristik Responden $(\mathrm{N}=24)$

\begin{tabular}{ll}
\hline Karakteristik & $\mathbf{n}(\%)$ \\
\hline Usia & \\
20-30 tahun & $3(12,5)$ \\
31-40 tahun & $11(45,8)$ \\
41-50 Tahun & $8(33,3)$ \\
51-60 Tahun & $2(8,3)$ \\
Jenis Kelamin & \\
Laki-laki & $14(58,3)$ \\
Perempuan & $10(41,7)$ \\
Pendidikan & \\
Tidak & $2(8,3)$ \\
Sekolah(Tidak & \\
tamat) & \\
Pendidikan & $11(45,8)$ \\
Dasar & \\
Pendidikan & $6(25,0)$ \\
Menengah & \\
Pendidikan & $5(20,8)$ \\
Tinggi & \\
Pekerjaan & \\
Tidak bekerja & $4(16,7)$ \\
Swasta & $14(58,3)$ \\
Wiraswasta & $1(4,2)$ \\
PNS/ABRI & $4(16,7)$ \\
Pensiunan & $1(4,2)$ \\
Hubungan & \\
Keluarga & \\
Anak & $8(33,3)$ \\
Istri & $1(4,2)$ \\
Suami & $2(8,3)$ \\
lbu & $5(20,8)$ \\
Saudara & $4(16,7)$ \\
Kandung & \\
Saudara dekat & $4(16,7)$ \\
\hline &
\end{tabular}

oksigen, monitoring EKG dan pulse oksimetri, pemberian nutrisi enteral dan nutrisi panenteral, pemeriksaan laboratorium khusus dan cepat, terapi secara tetrasi, fisioterapi dada, tehnik khusus sesuai kondisi pasien, tunjangan fungsi vital dengan alat portable selama transportasi. Berdasarkan kriteria sampel dan persyaratan dalam pemilihan sampel didapatkan sebanyak 24 responden.

\section{Karakteristik Responden}

Berdasarkan Tabel 1. menunjukkan bahwa dari 24 responden penelitian, sebagian besar berusia 31 - 40 tahun (45.8\%). Sebagian besar responden penelitian berjenis kelamin laki-laki $(58.3 \%)$. Sebagian besar responden berpendidikan dasar $(45,8 \%)$ dan paling sedikit tidak sekolah $(8,3 \%)$. Sebagaian besar responden bekerja sebagai swasta $(58.3 \%)$ dan paling sedikit sebagai pensiunan $(4,2 \%)$. sebagian besar responden Berdasarkan hubungan keluarga hubungan dengan anak $(33,3 \%)$ dan paling sedikit hubungan istri $(4,2 \%)$.

\section{Komunikasi terapeutik perawat dan Kecemasan Keluarga}

Tabel 2. Komampuan Komunikasi

Terapeutik Perawat dan Kecemasan

Pasien

\begin{tabular}{ll}
\hline Variabel & $\mathbf{n}(\%)$ \\
\hline $\begin{array}{l}\text { Kemampuan } \\
\text { Komunikasi Perawat }\end{array}$ & \\
$\begin{array}{l}\text { Sedang / cukup } \\
\text { Baik }\end{array}$ & $6(25,0)$ \\
Tingkat Kecemasan & $18(75,0)$ \\
Keluarga & \\
Tidak cemas & $4(16,7)$ \\
Ringan & $16(66,7)$ \\
Sedang & $3(12,5)$ \\
Berat & $1(4,2)$ \\
\hline
\end{tabular}

Tabel 2 menunjukkan bahwa sebagian besar responden menyatakan bahwa komunikasi terapetik yang dilakukan perawat termasuk kategori baik yaitu sebesar 75\%. Dari 24 responden penelitian, sebagian besar mengalami kecemasan ringan $(66.7 \%)$ dan terdapat $4.2 \%$ mengalami kecemasan berat. 
Tabel 3 Tabel Silang Komunikasi Terapeutik Perawat dengan Tingkat Kecemasan Keluarga

\begin{tabular}{|c|c|c|c|c|c|c|c|c|c|c|}
\hline \multirow{3}{*}{$\begin{array}{l}\text { Kemampuan } \\
\text { Komunikasi }\end{array}$} & \multicolumn{8}{|c|}{ Kecemasan } & \multirow{2}{*}{\multicolumn{2}{|c|}{ Total }} \\
\hline & \multicolumn{2}{|c|}{$\begin{array}{l}\text { Tidak } \\
\text { cemas }\end{array}$} & \multicolumn{2}{|c|}{ Ringan } & \multicolumn{2}{|c|}{ Sedang } & \multicolumn{2}{|c|}{ Berat } & & \\
\hline & f & $\%$ & $f$ & $\%$ & $f$ & $\%$ & $f$ & $\%$ & $f$ & $\%$ \\
\hline Baik & 4 & 22,2 & 14 & 77,8 & 0 & 0,0 & 0 & 0,0 & 18 & 100,0 \\
\hline Cukup & 0 & 0,0 & 2 & 33,3 & 3 & 50,0 & 1 & 16,7 & 6 & 100,0 \\
\hline Jumlah & 4 & 16,7 & 16 & 66,7 & 3 & 12,5 & 1 & 4,2 & 24 & 100,0 \\
\hline
\end{tabular}

\section{Hubungan Komunikasi Terapeutik perawat dan Tingkat Kecemasan Keluarga}

Berdasarkan Tabel 3, enam responden yang mendapatkan komunikasi terapetik dari perawat dengan kategori sedang sebagian besar mengalami kecemasan sedang (50\%), dan masih terdapat $16.7 \%$ yang mengalami kecemasan berat. Sedangkan dari 18 responden yang mendapatkan komunikasi terapetik dari perawat dengan kategori baik sebagian besar mengalami kecemasan ringan, bahkan terdapat $22.2 \%$ yang tidak mengalami kecemasan, dan tidak ada yang mengalami kecemasan berat.

Hasil analisis dengan menggunakan uji Spearman Rho diperoleh nilai $p$ sebesar 0.319 . Disimpulkan hipotesis nol diterima dan menolak hipotesis alternatif. Dengan demikian berarti tidak terdapat hubungan antara komunikasi terapeutik perawat dengan tingkat kecemasan keluarga pasien yang anggota keluarganya di rawat di ICU RSUD Kota Salatiga. Dimana arah hubungan yang bersifat negatif $(r=-0,213)$, yang berarti semakin tinggi komunikasi perawat semakin rendah tingkat kecemasan keluarga pasien yang berada di unit perawatan kritis.

\section{PEMBAHASAN}

\section{Komunikasi Terapeutik Perawat}

Berdasarkan hasil penelitian diketahui bahwa sebagian besar responden menyatakan bahwa komunikasi terapetik yang dilakukan perawat termasuk kategori baik yaitu sebesar $75 \%$. Komunikasi yang dilakukan oleh perawat dinilai baik oleh responden karena reponden sangat membutuhkan informasi yang tepat dan benar tentang kondisi anggota keluarganya yang dirawat. Untuk membantu meningkatkan perasaan pengendalian diri pada klien dan keluarga salah satunya dapat melalui pemberian informasi dan penjelasan (Hudak \& Gallo, 1997).

Faktor karakteristik perawat memegang peranan penting dalam melakukan komunikasi terapeutik. Di ruang ICU RSUD Kota Salatiga, latar belakang pendidikan perawat terdiri dari 13 orang D III Keperawatan (100\%) data dari RSUD Kota Salatiga, demikian juga dengan pengalaman lama kerja rata-rata telah bekerja lebih dari 5 tahun. Pada saat pendidikan pernah mendapatkan pelajaran komunikasi terapetik, perawat yang pernah mengikuti seminar tentang komunikasi terapetik. Berdasarkan karakteristik perawat tersebut, peneliti meyakini bahwa perawat di ruang ICU dapat berkomunikasi secara baik. 
Berdasarkan hasil penelitian menunjukkan bahwa dari 24 responden penelitian semua perawat dapat melakukan komunikasi terapeutik lebik baik.

Dari hasil penelitian yang dilakukan dimana komunikasi perawat didapatkan komunikasi sedang (25\%) ini terjadi dikarenakan perawat kurang melakukan pemberian informasi dan penjelasan kepada keluarga pasien secara baik, atau saat pemberian informasi kepada keluarga terlalu tergesa-gesa dikarenakan perawat segera menangani pasien yang mengalami kegawatan. Terkadang perawat dalam pemberian informasi atau penjelasan kepada keluarga pasien dilakukan setelah penanganan pasien yang mengalami kegawatan atau saat perawat melakukan tindakan emergency. Pada saat menangani pasien yang mengalami kegawatan/emergency perawat dituntut untuk terampil dan cekatan dalam menangani pasien dan diharapkan pasien dapat segera tertolong dan tidak terlepas dari jumlah perawat yang ada saat tindakan emergency pasien dilakukan.

\section{Kecemasan Responden}

Sebagian besar mengalami kecemasan ringan $(66.7 \%)$ dan terdapat $4.2 \%$ mengalami kecemasan berat. Kecemasan berat yang dialami oleh anggota keluarga yang menunggui pasien yang berada di unit perawatan kritis antara lain pasien tidak boleh ditunggui di dalam ruangan, kondisi pasien yang terminal, jam besuk yang hanya sebentar, melihat anggota keluarga yang bergelantungan alat medis.

Berdasarkan hasil penelitian didapatkan sebanyak 24 responden berdasarkan pendidikan paling banyak adalah lulusan SD sebanyak 11 responden $(45,8 \%)$ dan paling sedikit PT sebanyak 5 responden (20,8\%) Seseorang dengan pendidikan yang rendah belum banyak menguasai ilmu pengetahuan (Notoatmodjo,2003). Sementara seseorang dengan tingkat pendidikan yang tinggi,akan memiliki bermacam-macam pengalaman yang baru yang di dapat dari dunia pendidikannya selain juga pengalaman dalam bekerja. Tingkat pendidikan seseorang juga berdampak pada daya intelektual untuk memecahkan sebuah persoalan. Ansietas pada klien dan keluarga yang menjalani perawatan di unit perawatan kritis terjadi karena adanya ancaman ketidakberdayaan kehilangan kendali, perasaan kehilangan fungsi dan harga diri, kegagalan membentuk pertahanan, perasaaan terisolasi dan takut mati. Untuk membantu meningkatkan perasaan pengendalian diri pada klien dan keluarga dapat salah satunya dapat melalui pemberian informasi dan penjelasan (Hudak \& Gallo, 1997 : 11). Peneliti dalam membantu mengurangi kecemasan keluarga dengan cara melakukan komunikasi verbal yang efektif dengan Pemberian informasi dan penjelasan tentang keadaan pasien saat pasien masuk pertama ke unit perawatan kritis, setiap hari Serta saat keluarga pasien yang menunggui ingin mengetahui keadaan pasien saat itu.

\section{Hubungan antara komunikasi terapeutik perawat dengan tingkat kecemasan keluarga}

Berdasarkan hasil penelitian menunjukkan bahwa dari 6 responden yang mendapatkan komunikasi terapetik dari perawat dengan kategori sedang sebagian besar mengalami kecemasan sedang (50\%), dan masih terdapat $16.7 \%$ yang mengalami kecemasan berat. 
Sedangkan dari 18 responden yang mendapatkan komunikasi terapetik dari perawat dengan kategori baik sebagian besar mengalami kecemasan ringan, bahkan terdapat $22.2 \%$ yang tidak mengalami kecemasan, dan tidak ada yang mengalami kecemasan berat. Hasil analisis dengan menggunakan uji Spearman Rho diperoleh nilai $p$ sebesar 0.319. Disimpulkan hipotesis nol diterima dan menolak hipotesis 1 (alternatif). Dengan demikian berarti tidak terdapat hubungan antara komunikasi terapeutik perawat dengan tingkat kecemasan keluarga pasien yang anggota keluarganya di rawat di ICU RSUD Kota Salatiga.

Hasil penelitian ini tidak terdapat hubungan antara komunikasi terapeutik dengan kecemasan keluarga, hal ini dikarenakan bahwa kecemasan merupakan setiap perubahan dalam kehidupan atau peristiwa kehidupan yang dapat menimbulkan keadaan stres disebut stresor. Stres yang dialami seseorang dapat menimbulkan kecemasan, atau kecemasan merupakan manifestasi langsung dari stres kehidupan dan sangat erat kaitannya dengan pola hidup (Wibisono, 2000). Berbagai faktor predisposisi yang dapat menimbulkan kecemasan (Roan, 1989) yaitu faktor genetik, faktor organik dan faktor psikologi. Pada keluarga pasien yang anggota keluarganya menjalani perawatan di ruang ICU, faktor predisposisi kecemasan yang sangat berpengaruh adalah terutama ketidakpastian tentang perkembangan kesehatan anggota keluarga yang akan dijalani dan keadaan ruang ICU saat pasien mengalami keadaan yang kegawatan.

Ansietas pada klien dan keluarga yang menjalani perawatan di unit perawatan kritis terjadi karena adanya ancaman ketidak berdayaan kehilangan kendali, perasaan kehilangan fungsi dan harga diri, kegagalan membentuk pertahanan, perasaaan terisolasi dan takut mati. Untuk membantu meningkatakan perasaan pengendalian diri pada klien dan keluarga dapat salah satunya dapat melalui pemberian informasi dan penjelasan (Hudak \& Gallo, 1997). Pemberian informasi dan penejelasan ini dapat dilakukan dengan baik apabila didukung oleh pelaksanaan komunikasi verbal perawat yang efektif yaitu untuk menyampaikan informasi tentang keadaan pasien sesuai dengan wewenangnya.

Berbeda dengan hasil penelitian Rachmawati (2006) yang melakukan penelitian tentang hubungan komunikasi verbal dan non verbal perawat dengan tingkat kecemasan keluarga pada pasien yang dirawat di RS Rumkital dr. Ramelan Surabaya didapatkan hasil ada hubungan komunikasi perawat dengan tingkat kecemasan keluarga dengan nilai $p=$ 0,027 pada derajat kemaknaan $<0,05$.

\section{KESIMPULAN}

Berdasarkan hasil penelitian dan pembahasan dapat disimpulkan bahwa sebagian besar responden menyatakan bahwa komunikasi terapetik yang dilakukan perawat termasuk kategori baik $(75 \%)$. Sebagian besar responden mengalami kecemasan ringan (66.7\%) dan terdapat $4.2 \%$ mengalami kecemasan berat. Tidak terdapat hubungan antara komunikasi terapeutik perawat dengan tingkat kecemasan keluarga pasien yang anggota keluarganya di rawat di ICU RSUD Kota Salatiga $(p>0.05)$. 


\section{KEPUSTAKAAN}

Anderson. (2007). Acceptance of information, Juli 2, 2011. http://www. Sikunews.com/News/CanadaNunavik/6863.

Ann, M, T. (2008). Nursing theory. Philadelphia: Wilkin and Williams, Lippincott Company,.

Ariawan, I.. (1998). Perkiraan besar sampel penelitian. Jakarta: FKM UI,

Arikunto, S. (2006). Prosedur penelitian suatu pendekatan praktek. Jakarta: Penerbit Rineka Cipta.

Aswar. S. (2000). Skala psikologi. Yogayakarta: Penerbit Pustaka Pelajar

Atkinson, R.L. et all. (2000). Pengantar Psikologi. Alih bahasa Wijaja Kusuma. Batam: Interaksara.

Baron, S. (2008). Psikologi kesehatan. Jakarta: Gramedia Widia Sarana Indonesia.

Chandra Budiman. (2005). Pengantar Statistik Kesehatan. Cetakan I. Penerbit Buku Kedokteran EGC. Jakarta.

Craven R dan Himle C. (2000). Fundamental of nursing, 3rd edition, Philadelphia: Lippincott.

Depkes RI (2004). Pedoman perawatan psikiatri. Jakarta: Depkes RI,

Effendi, (2002). IImu kesehatan masyarakat. Jakarta: Balai Pustaka.

Ellis, R.B. \& Nowlis, M, E.. (2004). Komunikasi interpersonal dalam keperawatan teori dan praktik, Alih bahasa: Susi Purwoko, Editor : Setiawan, Jakarta: EGC.

Furukawa, M.M. (2006). Meeting the needs of the dying patient's family. Journal of Critical Care Nurse 16 (1): 51-57.

Hamid, A.Y.S., (2003). Komunikasi terapeutik .Jakarta: EGC.
Hudak, G., \& Gallo, B. M. (2001). Keperawatan kritis pendekatan holistik. Volume I Edisi VI. Jakarta : EGC.

Ivey. (2008). The nurse's role and skill in critical care. Lippincott Williams \& Wilkins medscape nurses. Juli 10 , 2011.

http://www.medscape.com/viewarticl es/463185

Keliat. B.A. (2006). Hubungan terapeutik perawat - klien. Jakarta: EGC.

Kariyoso. (2004). Pengantar komunikasi bagi siswa perawat. EGC. Jakarta

Leddy. (2008), Tingkat Kecemasan. Juli 10, 2011. http://leddy.wordpress.com/2009/08/ 25/kecemasan.

Ley dan Spelman (2002), Critical illness as biographical disruption. April 7, 2011

http://www3.interscience.wiley.com/c gi_bin/fulltext/119562079/PDFSTAR $T$

Maramis, A. (2000). IImu kesehatan jiwa. Jakarta EGC

Mulyana, D. (2000). IImu komunikasi suatu pengantar. Editor: Muchlis. PT Rermaja Rosdakarya. Bandung.

Notoatmodjo. (2003). Metodologi Penelitian Kesehatan. Rineka Cipta. Jakarta

Nurjannah, I. (2001). Hubungan terapeutik perawat dan klien. Yogyakarta: Program Studi IImu Keperawatan Fakultas Kedokteran UGM.

Scott, B. (1990). Ketrampilan berkomunikasi. Jakarta: Bina Rupa Aksara.

Nursalam \& Pariani, S (2000). Metodologi riset keperawatan. CV Jakarta: Sagung Seto.

Pennock, (2004). Managemen anxiety ini nursing, corelational study. Juli 4 , 2011. 
http://www.ncbi.nlm.nih.gov/pmc/artic les/ PMC 1836829.

Potter, P.A. \& Perry, A.G. (2005). Buku ajar fundamental keperawatan: konsep,proses, dan praktek. Edisi 4. volume 2, Jakarta: EGC.

Reigel (1999). Factors associated with critical illness. Asia pasific journal of public health. Vol 16. no. 2. Agustus 6, 2011.

http://aph.sagepub.com/cgi/content/a bstract/16/2/109

Rosdahl, (2009). Anxiety but not depression is associated with critical care. Juli 3, 2011.

http://www.Psychosomaticmedicine.o $\mathrm{rg} / \mathrm{c} / \mathrm{cgi} /$ content/full/61/1/77

Roy, S.C. (1991). The Roy adaptation model: the definitive statement. New Jersey: Appleton-Century

Rungapadiachy, (2009), therapeutic communication in nursing, http://newforestphysio.com/yahoo_sit e_admin/assets/docs/biographical_di sruption_ass1.339180037.pdf.

Rusmini. (2005). Penerapan komunikasi terapeutik oleh perawat, Skripsi, tidak di terbitkan).
Saelan (2008), Pendekatan komunikasi terapeutik dengan pasien, Skripsi, tidak di terbitkan)

Smet, (2004), Psikologi kesehatan. Jakarta: Gramedia Widia Sarana Indonesia.

Smith, S.F. (1996). Clinical Nursing Skill : Basic to Advanced Skill. 4th.ed. Conecticut: Stanford.

Stuart, G.W., and Sunden, S.J., (1998). Buku saku keperawatan jiwa. edisi 3 (alih bahasa). Jakarta : EGC..

Stuart, G.W. (2009). Principles and Practice of Nursing Psychiatric. 9th edition. Mosby Year Book. St. Louis Philadelphia.

Tomey, M. A., (2006). Nursing Theory. Philadelphia: Wilkin adn Williams Lippincott Company,.

Townsend. (2008). Diagnosa keperawatan jiwa, (Terjemahan), , Jakarta: EGC.

Videbeck, S.L., (2008), Buku ajar keperawatan jiwa (Terjemahan), Jakarta: EGC. 